\title{
PHYSICIAN INFLUENCE: APPLYING NOERR-PENNINGTON TO THE MEDICAL PROFESSION
}

The medical profession, like any other form of business, subjects itself to potential antitrust liability when it engages in joint activity designed to affect trade relations. One type of joint activity used by the profession is the influencing of government bodies in order to attain anticompetitive results favorable to physicians. This kind of joint effort in the commercial world is to some extent protected from the antitrust laws by the Noerr-Pennington doctrine. It is not at all clear, however, to what degree this defense is available in the medical context.

This Note will focus on the proper scope of the Noerr-Pennington defense in the context of five case studies of actual or potential medical antitrust cases. In each case, the potential antitrust violation is described in sufficient detail to highlight the significance of the NoerrPennington doctrine. This description is then followed by a discussion of the proper use of the Noerr-Pennington defense. Through analyzing the applicability of the Noerr-Pennington defense in each of the five cases, this Note will examine the constitutional basis underlying the doctrine, the judicially created exceptions, and the defense's limited application to the activities of quasi-public, self-regulatory medical organizations.

\section{Noerr-Pennington: The Legal Doctrine}

Eastern Railroad Presidents Conference v. Noerr Motor Freight, Inc. ${ }^{1}$ was the first case exempting from the Sherman Act joint activities aimed at attaining anticompetitive governmental decisions. In Noerr several railroads had engaged in an intense publicity campaign in order to influence legislation and obtain executive enforcement of laws that would eliminate trucking companies as competitors for the lucrative long distance heavy freight business. ${ }^{2}$ This publicity campaign involved the use of front organizations that would send letters to State legislators and the governor, making it seem as if public sentiment was against the truckers. ${ }^{3}$ The railroads were successful in their efforts, and the truck-

1. 365 U.S. 127 (1961).

2. Id. at $142-43$.

3. Id at 133. 
ing companies brought an antitrust suit based on the railroads' anticompetitive purpose and their use of a fraudulent publicity campaign. ${ }^{4}$

The lower courts found the railroads' activities were malicious and fraudulent and constituted a violation of the Sherman Act; 5 however, the Supreme Court reversed. In its opinion the Court put forth two reasons for not applying the Sherman Act: first, Congress' intent was to regulate monopolistic business practices and not political activity designed to inform the executive and legislative branches of government; and second, serious first amendment issues regarding the right to petition the government would be raised if the Sherman Act were construed to cover the lobbying activities of the railroads. ${ }^{6}$ The Court further stated that the purpose behind the political activity and the manner in which the activity was conducted ${ }^{8}$ were relevant considerations in the determination of whether or not the activity was immune from the antitrust law. However, these factors were relevant if it could be shown that the "publicity campaign, ostensibly directed toward influencing governmental action, [was] a mere sham to cover what [was] actually nothing more than an attempt to interfere directly with the business relationships of a competitor." This caveat to the Court's holding established what has come to be called the "sham exception."10

Four years later the Court in United Mine Workers v. Pennington ${ }^{11}$ faced a similar question involving the joint efforts of the mine worker's union and large mine operators to force small coal producers out of business. ${ }^{12}$ In Pennington the large mine owners and the union lobbied with the Secretary of Labor in order to persuade him to use his authority under the Walsh-Healy $\mathrm{Act}^{13}$ to set higher wages for employees of

4. Id. at 129-30.

5. Noerr Motor Freight, Inc. v. Eastern R.R. Presidents Conference, 155 F. Supp. 768 (E.D. Pa. 1957), affd, 273 F.2d 218 (3d Cir. 1959), rev'd, 365 U.S. 127 (1961).

6. Id. at 137-38. Since Noerr some confusion has existed in the lower courts as to whether the decision was based on statutory construction or first amendment grounds. Compare Bethlehem Plaza v. Campbell, 403 F. Supp. 966, 969 (E.D. Pa. 1975) (constitutional basis) with Cow Palace, Ltd. v. Associated Milk Producers, Inc., 390 F. Supp. 696, 701-02 (D. Colo. 1975) (primarily statutory grounds).

7. 365 U.S. $127,138-40$ (1961). The Court specifically stated that the legality of the railroads' publicity campaign was "not at all affected by any anticompetitive purpose it may have had." Id. at 140.

8. Id. at 140-42. The Court noted that the Sherman Act applied to the ethics of activities involving trade restraints and not political activity. Id. at 140.

9. Id. at 144.

10. See text accompanying notes 53-60 infra.

11. 381 U.S. 657 (1965).

12. Id. at $657-60$.

13. 41 U.S.C. $\S \S 35-45$ (1970). Under the Act the Secretary of Labor has the power to set, 
firms selling coal to the TVA. ${ }^{14}$ Further, this group urged the TVA to curtail its buying from small coal operators in the spot market. ${ }^{15}$ In its decision the Supreme Court held that the activities of the mine owners and the union were immune from the antitrust laws ${ }^{16}$ and simultaneously extended the principle of Noerr by stating that "joint efforts to influence public officials do not violate the antitrust laws even though intended to eliminate competition."17

The final Supreme Court decision to add significantly to the doctrine was California Motor Transport Co. v. Trucking Unlimited. ${ }^{18}$ In California Motor Transport a group of trucking companies pursued a practice of instituting state and federal administrative proceedings against a rival, Trucking Unlimited, whenever Trucking Unlimited would file for operating authority. ${ }^{19}$ Trucking Unlimited claimed that this harassment through the use of administrative action had the effect of eliminating it as a competitor. ${ }^{20}$

In its opinion the Court dealt with two basic aspects of the Noerr and Pennington cases. First, the Court extended the antitrust immunity to cover concerted efforts before adjudicatory bodies by relying on the first amendment right to petition the government for redress of grievances. ${ }^{21}$ This portion of the decision was a logical extension of the

within reasonable limits, the minimum wages that will be paid to employees of government contractors. 4 I U.S.C. \& 35 (b) (1970).

14. 381 U.S. at 660 .

15. Id. at $660-61$.

16. Id. at 670 .

17. Id. (emphasis added). The broad sweep of the statement by Mr. Justice White has been criticized for ignoring the underlying basis of the Noerr decision, that the Sherman Act is aimed at economic activity and should not be applied so as to interfere with the political decision making process. Note, Application of the Sherman Act to Attempts to Influence Government Action, 81 HARV. L. REv. 847, 852 (1968). One commentator has observed that "the implication of Noerr and Pennington are only limited by one's imagination." Costilo, Antitrust's Newest Quagmire: The Noerr-Pennington Defense, 66 MiCH. L. Rev. 333, 339 (1967). Subsequent to the Pennington decision, some lower courts began to apply mechanically the doctrine whenever a private organization or group of businesses would infiuence a government official. See Household Good Carrier's Bureau v. Terrell, 452 F.2d 152 (5th Cir. 1971) (purchase of goods by government); Sun Valley Disposal Co. v. Silver State Disposal Co., 420 F.2d 341 (9th Cir. 1969) (award of government contracts); United States v. Johns-Manville Corp., 259 F. Supp. 440 (E.D. Pa. 1966) (influence of product specifications for government contracts).

18. 404 U.S. 508 (1972).

19. Id. at 509 .

20. Trucking Unlimited v. California Motor Transport Co. [1967] Trade Cas. (CCH) \ 72,298 at 84,740 (N.D. Cal.), rev'd, 432 F.2d 755 (9th Cir. 1970), aff'd, 404 U.S. 508 (1972).

21. 404 U.S. 510-11. Fischel, Antitrust Liability for Attempts to Infuence Government Action: The Basis and Limits of the Noerr-Pennington Doctrine, 45 U. CHI. L. REv. 80, 94-96 (1977); see Handler, Twenty-five Years of Antitrust, 73 Colum. L. Rev. 415, 435 (1973). The use of the first amendment right of petition as a basis for the decision was not necessary. The Noerr Court had interpreted the Sherman Act in such a way that it did not apply to situations involving business 
principle expressed in both Noerr and Pennington in that concerted activities before governmental bodies, even though for anticompetitive ends, do not, standing alone, violate the Sherman Act. Just as the legislative and executive branches need information from the private sector to make policy decisions, so do courts and administrative tribunals. ${ }^{22}$ Yet, in extending the immunity the Court's opinion did little to establish any clear guidelines for future decisions. Instead the verbal formula expressed in Noerr and Pennington continues to be the only guidepost. ${ }^{23}$

In the second part of the opinion, the Court did explain to some degree the scope of the sham exception first noted in Noerr. The Court stated that although "misrepresentation" is condoned in the political arena, it is not immunized when used in the adjudicatory process. ${ }^{24}$ By differentiating between the political world and adjudicatory hearings, the Court created a dual standard under the sham exception. ${ }^{25}$ In the judicial-administrative setting a "sham" is easier to prove because the complaining party need only show that the defendant's activities abused the judicial process, rather than prove that the defendant's acts were a cover for a direct interference in the complainant's business.

In order to more clearly delineate the scope of the NoerrPennington doctrine as applied to the medical profession, this Note will

activities aimed at informing executive and legislative bodies. This construction can be applied to adjudicatory bodies since they also need information in order to decide policy-laden disputes between competing litigants. See Note, Limiting the Antitrust Immunity for Concerted Altempts to Infuence Courts and Adjudicatory Agencies: Analogies to Malicious Prosecution and Abuse of Process, 86 HARv. L. Rev. 715, 722 (1973).

22. For example, many administrative agencies, such as the ICC, conduct evidentiary hearings on issues involving the particular regulated business. As Professor Davis points out, the agency considers both specific adjudicatory facts dealing with the parties involved and general legislative facts concerning the type of policy to be implemented. $1 \mathrm{~K}$. DAVIS, ADMINISTRATIVE LAW TREATISE $\$ 7.02$ at 413 (1958); see Note, supra note 21, at 722 n.43. A specific example of this type of agency action can be found in the ICC's policy decision to restrict circuitous operating practices of motor carriers that involve a wasteful use of fuel. Motor-Common Carriers of Property, Routes, and Serv., 119 M.C.C. 530 (1974).

23. Most lower court decisions start with the proposition that the activity is immune from the Sherman Act unless it can be shown by the complainant that the activity falls into an exception. See, eg., Metro Cable Co. v. CATV of Rockford, Inc., 516 F.2d 220, 224-28 (7th Cir. 1975); RushHampton Indus., Inc. v. Home Ventilating Inst., 419 F. Supp. 19, 22-25 (M.D. Fla. 1976); Bethlehem Plaza v. Campbell, 403 F. Supp. 966, 969-71 (E.D. Pa. 1975).

24. 404 U.S. at 513.

25. See Metro Cable Co. v. CATV of Rockford, Inc., 516 F.2d 220, 228 (7th Cir. 1975); Note, The Quagmire Thickens: A Past-California Motor View of Antitrust and Constitutional Ramifications of Petitioning the Government, 42 U. CiN. L. REv. 281, 303-05 (1973). Mr. Justice Stewart in his Caljfornia Motor Transport concurrence noted that the difference in the type of governmental body might make a difference in the applicability of the antitrust laws if the petitioner had made misrepresentations or had engaged in perjury, fraud or bribery. 404 U.S. at 517. 
analyze five case studies. Each one involves a possible antitrust violation, but similarly each one raises a possible Noerr-Pennington defense.

\section{NOERR-PENNINGton AND the Medical Profession: Five CASE STUdies}

\section{A. Medicare Strikes.}

The primary forum for organizing physicians for economic purposes is the American Medical Association (AMA) and its component medical societies. ${ }^{26}$ By using the mechanisms of professional ostracism, ${ }^{27}$ backed up by reprimand, suspension or expulsion ${ }^{28}$ the medical societies are able to enforce their standards of conduct. Because of this power over the individual physician's earning capacity and professional status, the formation of joint activities against economically threatening competitors, suppliers and customers is relatively easy. ${ }^{29}$

One example of concerted activity involves the refusal of a local medical society's members to accept Medicaid patients. ${ }^{30}$ By refusing to treat these patients, the physicians are pressuring both state and federal governments into paying higher fees in order to have the Medicaid program continue.

26. See Note, The American Medical Association: Power, Purpose, and Politics in Organized Medicine, 63 YALE L.J. 938, 942 (1954). In order for a physician to belong to the national organization, he must first be admitted to the county medical society. E. FREIDSON, PROFESSION OF Medicine: A Study of the Sociology of Applied Knowledge 27 (1970); E. Rayack, Professional Power and American Medicine: The Economics of the AMERICAN Medical Association 3 (1967).

27. Rayack, Restrictive Practices of Organized Medicine, 13 ANTITRust Bull. 659, 665-66 (1968); Note, supra note 26, at 949; see Group Health Coop. v. King County Medical Soc'y, 37 Wash. 2d 586, 626, 237 P.2d 737, 759 (1951) (non-member regarded as social outcast). Professor Freidson has noted that the basic feature of the medical profession's system of control is its reliance on the "boycott," which he defines as "the refusal by individual practitioners to enter into a referral or collaborative relationship with those of whom they do not approve." E. FREIDSON, Professional Dominance: The Social Structure of Medical Care 94 (1970). However, this sanction does not control the boycotted doctor's behavior, but rather has the effect of pushing the physician outside of the observation and influence of those who disapprove of his work and into the company of those with similar standards. Id. Consequently, Freidson argues that the controls used by the profession operate to place the disapproved-of doctors beyond the control of the disapproving group. Id. 101.

28. Note, supra note 26 , at 950 .

29. See Note, supra note 26, at 988; MED. WORLD NEws, Jan. 26, 1976, at 6.

30. Recently, a Massachusetts ophthalmologist refused to treat a young child upon learning that he was a Medicaid recipient. Am. Med. News, Jan. 31, 1977 at 12, col. 1. Reportedly, the physician told the patient's general practitioner that no specialist in the area would see the child. Id. In response to the incident, the Massachusetts Medical Society has taken the position that those doctors who do not participate in the Medicaid program are free to choose their patients. Id 
This action against Medicaid patients constitutes a concerted refusal to deal, and violates section one of the Sherman Act ${ }^{31}$ since it unnecessarily restrains competition. ${ }^{32}$ The doctors, as individual competitors, have conspired in order to force a consumer-in this case the government-to accept their joint terms. By organizing together, the physicians eliminated competition among themselves for the sole purpose of setting the price charged the state and federal governments. Moreover, the refusal to deal does not serve any non-commercial purpose $^{33}$ - the only aim is to increase doctors' income-and consequently unduly restricts competition within the meaning of section one. ${ }^{34}$

In defense, however, it could be argued that this type of concerted physician activity is simply an effort to influence the state's funding of its Medicaid program and is therefore protected by the NoerrPennington umbrella.

There are strong reasons, however, why the Noerr-Pennington doctrine should not apply in this type of case. Although the NoerrPennington defense has been upheld when the influencing activity involved sought to have a governmental body make an anticompetitive decision, in this instance the type of influencing activity used is in itself anticompetitive, irrespective of the eventual government decision. A

31. A physician's strike is not exempt from antitrust liability because of the immunity given to labor unions. See Craver, The Application of Labor and Antitust Laws to Physician Unions: The Need for Re-evaluation of Traditional Concepts in a Radically Changing Field, 27 HASTINGS L.J. 55,59 (1975).

32. Professor Sullivan argues that a concerted refusal to deal is distinguishable from a classic boycott. Under his definition a boycott occurs only when a group of businessmen at one economic level (e.g., retail) combine to pressure suppliers into refusing to trade with a non-group competitor, so both the purpose and effect of the boycott are to eliminate a competitor from the market. L. SULLIVAN, HANDBOOK OF THE LAW OF ANTITRUST 230 (1977). In contrast, a concerted refusal to deal is organized not to eliminate a competitor but to obtain a favorable trade advantage (e.g., higher prices or restrictive contracts) for the group. Id. 257.

In the boycott situation Professor Sullivan suggests that the courts have imposed a per se standard where the facts involve a distinctly anticompetitive purpose and effect. However, in the concerted refusal to deal situation, the refusal may be based on legitimate reasons serving a useful social purpose, (such as refusing to deal with a manufacturer of unsafe products) and thus only constitutes an antitrust violation when the refusal to deal unreasonably restricts competition. Id. 256-59.

33. An example of a non-commercial purpose for a concerted refusal to deal would be an agreement by competitors not to use a harmful substance made by certain suppliers in a children's product. L. Sullivan, supra note 32, at 259. See also Deesen v. Professional Golfers Ass'n, 358 F.2d 165, 170 (9th Cir.), cert. denied, 385 U.S. 846 (1966).

34. This activity is closely analogous to that of the suppliers of movie films in Paramount Famous Lasky Corp. v. United States, 282 U.S. 30 (1930). In that case the film distributors agreed to use only a contract which required the arbitration of disputes. Id. at 37-40. The Supreme Court found that the refusal to deal, except on the terms dictated, unreasonably suppressed competition and thus violated the Sherman Act. Id. at 43. In the case of the doctors, the finding of a section one violation would be even more compelling. 
doctors' strike is qualitatively different from the many forms of "armtwisting" lobbying efforts that the courts have found to be reprehensible, but still within the protection of the doctrine. ${ }^{35}$ Since the means used in the physicians' influencing effort itself involves a violation of the Sherman Act, the normally impregnable first amendment barrier to restricting petitioning of government becomes subject to a careful process of judicial balancing. As Justice Douglas, a near-absolutist in first amendment jurisprudence, observed in California Motor Transport, "it is well settled that first amendment rights are not immunized from regulation when they are used as an integral part of conduct which violates a valid statute." 36 The harm caused by limiting the right to influence government can thus be legitimately weighed against the social harm caused by the boycott.

In this case the harm involves the inability of the Medicaid patient to receive treatment in the clinics of these practitioners. Treatment is delayed and necessitates the inconvenience of either using a hospital or traveling to a non-boycott area. ${ }^{37}$ Clearly, such a boycott frustrates the congressional health policy ${ }^{38}$ and violates the Sherman Act. On the other hand, the doctors could argue that boycotting was the most immediate and effective way of petitioning for relief. However, as in the free speech cases, reasonable alternatives to the boycott should be considered. ${ }^{39}$ The physicians have other means of influencing government policy through more traditional lobbying activities. Consequently, use of such a balancing test suggests that the Noerr-Pennington doctrine should not apply.

35. For example, the Court in Noerr found the publicity scheme to be reprehensible, but since it was a political activity, it was not within the sanctions of the Sherman Act. 365 U.S. at $140-41$.

36. 404 U.S. 508,514 (1972).

37. Under the Medicaid Act if a state accepts federal funds, its plan for medical assistance must provide that any eligible person may obtain the medical services needed from any qualified person or organization that undertakes to provide them. 42 U.S.C.A. § 1396a (West Supp. 1978). Under this provision treatment could be obtained at a participating hospital.

38. See 42 U.S.C.A. $\$ \S 1396-1396 i$ (West Supp. 1978).

39. For example, in the free speech case of Lloyd Corp. v. Tanner, 407 U.S. 551 (1972), Vietnam War protesters were arrested for trespassing while distributing anti-war handbills in a privately-owned shopping center. Rejecting the war protesters' first amendment defense, the Supreme Court stated that since alternative avenues of communication existed through the use of nearby public property, it would be an unwarranted infringement on the owner's property rights to require his rights to yield to the first amendment rights of the protesters. Id. at 556-57.

Similarly, in the case of the doctors' Medicaid boycott alternative avenues of communication exist through the use of lobbyists and letter campaigns. Since these reasonable alternatives are available, the Congressional policy of free competition as expressed through the antitrust laws should not give way to the physicians' first amendment based Noerr-Pennington defense. 
A second justification for not applying Noerr-Pennington in this situation is that the nature of the dispute-the proper price to pay for medical services-suggests that the doctors' strike is within the judicially created consumer exception to the Noerr-Pennington doctrine. ${ }^{40}$ The consumer exception was first presented in George R. Whitten, Jr., Inc. v. Paddock Pool Builders, Inc. ${ }^{41}$ which involved competing dealers in the pipeless swimming pool market. Both companies sought to foreclose the other by persuading the school board's architect to include specifications in the plans that only one of the two companies could meet. ${ }^{42}$ In ruling on the Noerr-Pennington defense the court pointed to the political nature of the decision made in Noerr and contrasted the economic decision being made by the school board in the case before the court. ${ }^{43}$ Since the school board had already decided to build the pool, ${ }^{44}$ it was acting as any other consumer in obtaining the best product at the lowest cost. The school board was not engaged in a policy determination, but merely acting as an economic decision maker under a competitive bidding statute. Consequently, the efforts to influence that decision were outside of the Noerr-Pennington doctrine's immunity. ${ }^{45}$

By focusing on the type of government decision being made, the Court must distinguish between policy decisions and economic transactions. This distinction, however, will not always be easy; many spending programs are not only economic transactions but involve policy considerations as well. ${ }^{46}$ In order to determine whether the NoerrPennington doctrine should apply in these situations a court should balance the degree of purely economic activity against the public policy

40. Both the First Circuit in George R. Whitten, Jr., Inc. v. Paddock Pool Builders, Inc., 424 F.2d 25, 31-34 (1st Cir.), cert. denied, 400 U.S. 850 (1970), and the District of Columbia Circuit in Hecht v. Pro-Football, Inc., 444 F.2d 931, 940-42 (D.C. Cir. 1971), cert. denied, 404 U.S. 1047 (1972), have recognized this exception. The Fifth Circuit initially accepted the rationale of this exception in Woods Exploration \& Producing Co. v. Aluminum Co. of America, 438 F.2d 1286, 1297 (5th Cir. 1971), cert. denied, 404 U.S. 1047 (1972), but later in Household Goods Carriers' Bureau v. Terrell, 452 F.2d 152, 158-59 (5th Cir. 1971) rejected it. In United States v. JohnsManville Corp., 259 F. Supp. 440 (E.D. Pa. 1966), an early post-Noerr decision, the court did not consider the government's role as a consumer in its decision, even though it was a factor in the case.

41. 424 F.2d 25 (1st Cir.), cert. denied, 400 U.S. 850 (1970).

42. Id. at 28.

43. Id. at 32. Seizing upon the political aspect of the Noerr opinion, the court characterized the government decision in that case as involving "some significant policy determination" while the decision in Whitten dealt with "the best kind of weld to use in a swimming pool." Id.

44. Id. at 28.

45. Id. at 33 .

46. Id. at 34. A specific example can be found in the Pennington decision itself. Under the Walsh-Healy Act the Secretary of Labor in contracting for goods is required to insert minimum wage levels for employees of the contracting party. 41 U.S.C. \& 35(b) (1970). 
decision implicit in making the expenditure. Where the public policy question outweighs the economic decision being made, influencing activity should be protected by the doctrine; however, where the primary decision concerns the price paid for particular goods or services, the consumer exception should apply.

The use of this balancing test in the case of the doctors' Medicaid strike suggests that the government's funding is primarily an economic transaction. The policy decision to implement the Medicaid program has already been made, leaving only the economic question of how much money to spend. Characterized in this manner the case becomes analogous to Whitten, since it involves a purely commercial transaction between the government as buyer and physicians as sellers. Consequently, the Medicaid strike falls within the definition of the consumer exception and nullifies the use of the Noerr-Pennington doctrine as an effective defense.

\section{B. Malpractice Insurance Strikes.}

Another type of refusal to work in which medical societies have become involved is a work stoppage to protest the high cost of medical malpractice insurance. In this situation the work stoppage is not an effort aimed at setting a fee or eliminating a competitor, but rather it is an attempt to force the state government to alleviate the rise in insurance premiums. The refusal to work affects the insurers' ability to charge the market rate for insurance, since insurers must seek rate increase approval from the state. By putting pressure on the state insurance commission through the work stoppage, the doctors are able to reduce the requested increase. ${ }^{47}$

This type of organized resistance to the sellers' prices can be compared with other forms of joint buyer activity against sellers. In the commercial context when a well-organized group of buyers refuses to purchase goods or services except for the demanded price, the market price is affected. ${ }^{48}$ This kind of interference with the sellers' price is simply the reverse of an organized group of sellers setting an artificially high price for buyers. ${ }^{49} \mathrm{In}$ both situations the organized group is able to distort the competitive market price. Although few cases have dealt

47. For example, southern California physicians engaged in two work stoppages in order to lower medical malpractice insurance rates. At that time one insurer was seeking a $486 \%$ increase but was limited to $327 \%$ by the state insurance commission. MED. WORLD NEws, supra note 29, at 6.

48. See R. LiPSEY \& P. STEINER, ECONOMICs 349-50 (3d ed. 1972) (discussion in context of labor market).

49. See, e.g., United States v. Trenton Potteries Co., 273 U.S. 392, $397-98$ (1927). 
with the organized buyers' effect on the market, those that have suggest that if the purpose for the refusal to buy was to interfere in the sellers' commercial dealings, it would constitute an antitrust violation. ${ }^{50}$

Similarly, in the medical malpractice work stoppage the doctors are involved in an effort to interfere with the insurers' price. Although the work stoppage is not a direct refusal to buy, it accomplishes the same objective through a powerfully persuasive indirect route. If direct interference with the sellers' price is illegal, then an indirect method that seeks the same goal should also be illegal. Consequently, the physician medical malpractice work stoppage should be regarded as an indirect form of price control violative of the Sherman Act.

This type of case again confronts the question of the doctors' first amendment right to petition as expressed through the NoerrPennington defense. Using the balancing test developed above, ${ }^{51}$ the scope of the constitutional right to petition should be determined by balancing the social harm against the need to use this form of communication. The harm caused in this case is the denial of nonemergency medical services to a large number of patients, especially those who would be unable to travel to non-strike areas to obtain medical care. ${ }^{52}$ On the other hand, the doctors' position would be that there existed an immediate need to inform the government of their insurance plight. However, the physicians' strike is not the only method of influencing the state's legislative and executive bodies. Reasonable alternatives through traditional lobbying efforts do exist and do not result in the loss of medical services for a large segment of an area's population. Consequently, the balancing test suggests that the Noerr-Pennington doctrine should not apply since the amount of social harm outweighs the need to use the strike as a method of informing the government.

50. A distinction has been made between the refusal of organized buyers to purchase for religious, social, political or other noncommercial purposes and one designed to further the buyers' commercial and economic interests. In the former cases the reasonableness and legitimate purpose for the refusal to buy have influenced the courts in not finding an antitrust violation; see Community Blood Bank, 70 F.T.C. 728, 969-72 (1966) (Commissioner Jones, concurring), rev'd on other grounds, 405 F.2d 1011 (8th Cir. 1969). But see Council of Defense of State of New Mexico v. International Magazine Co., 267 F. 390 (8th Cir. 1920) (organized refusal to buy on grounds that seller was unpatriotic found to violate Sherman Act); Wall St. J., Mar. 16, 1978, at 1, col. 5 (Nevada and Missouri, anti-ERA states, instituting antitrust suits against women's group for boycotting the hotels in the state). However, in the latter cases the purpose for the refusal to buy was purely economic, and thus it qualified as the type of activity that the Sherman Act was intended to protect against. See United States v. Socony-Vacuum Oil Co., 310 U.S. 150, 223 (1940) (combination formed to set price is a Sherman Act violation). See generally Coons, Non-Commercial Purpose as a Sherman Act Defense, 56 Nw. U.L. REv. 705 (1962).

51. See text accompanying notes 35-39 supra.

52. Not only would the patient suffer, but area hospitals would stand to lose substantial revenues from the loss of patients. See MED. WORLD NEws, supra note 29, at 6. 
Further, even if the strike is considered within the scope of the right to petition, the method used may be characterized as a cover for direct interference in the insurers' business relations and fall within the sham exception to the Noerr-Pennington doctrine. Under the sham exception, as applied to the influencing of executive-legislative bodies, the complaining party must demonstrate that the influencing activity was "nothing more than an attempt to interfere directly with the business relationships of a competitor." 53 This test is very difficult to satisfy, as

a genuine effort to influence public officials can never violate the antitrust laws, regardless of what the defendant's direct or ulterior intentions may be. The sham exception applies only where the defendant is not really seeking to elicit government action at all. ${ }^{54}$

Since the sham exception for legislative-executive bodies is difficult to prove, the only post-Noerr case to discuss this point is Franchise Realty Interstate Corp. v. San Francisco Local Joint Executive Board of Culinary Workers. ${ }^{55}$ In Franchise Realty a subsidiary of McDonald's Corporation sought to obtain licenses from the City of San Francisco for three additional restaurants. ${ }^{56} \mathrm{~A}$ local union and several restaurant owners repeatedly opposed McDonald's applications and were successful in having them denied. ${ }^{57} \mathrm{McD}$ onald's filed an antitrust action against the union and restaurateurs, but this action was dismissed by the Ninth Circuit on the basis of the Noerr-Pennington doctrine. ${ }^{58}$ The court held that the legislative-executive sham exception applied only to a publicity campaign ${ }^{59}$ and not to direct lobbying efforts. Furthermore, the court noted that even if the exception applied to all lobbying efforts the sham exception was applicable only if the influencing party was not seeking any official action by a governmental body. ${ }^{60}$ This requirement that the complainant show that the defendant was not seeking any governmental action severely limits the usefulness of the exception since

53. Eastern R.R. Presidents Conference v. Noerr Motor Freight, Inc., 365 U.S. 127, 144 (1961).

54. Handler, supra note 21, at 436. Professor Handler goes on to state that the sham exception of Noerr is so limited that it would be difficult for a case to fall within this limitation of the doctrine. Id.

55. 542 F.2d 1076 (9th Cir. 1976), cert. denied, 430 U.S. 940 (1977).

56. 542 F.2d at 1078 .

57. Id. McDonald's claimed that the labor union's activities before the board were a sham because the union's opposition was baseless, and augmented with threats of withdrawing the union's political support for board members.

58. Id. at 1086.

59. Since the union's alleged sham activities were before licensing boards, this case more closely approximated the sham activities alleged in California Motor. The court's discussion of Noerr's sham limitation was thus unnecessary for its decision.

60 . 542 F.2d at 1081 . 
the defendant can easily make his activities appear as a legitimate attempt to obtain legislative or executive approval for his position.

This restrictive interpretation of the executive-legislative sham exception makes its applicability to the doctors' malpractice insurance strike questionable for two reasons. First, in order to use the exception it must be shown that the strike was an attempt to directly interfere with the business relations of another. ${ }^{61}$ This requirement is difficult to meet since the striking doctors are not interfering with a competitor's business relations but are affecting the relationship of a third party-the insurer-with its regulator-the state government. As no court has extended the sham exception to cover the effects of influencing activity on related businesses, an extension is unlikely under the current restrictive interpretation of the sham exception. ${ }^{62}$

Second, even assuming the extension of the scope of the sham exception, the physicians' strike can easily be characterized as an attempt to inform the government and to petition for relief. Since insurance is a highly regulated industry and involves substantial state policy, ${ }^{63}$ the legislated effects on the insurer due to the physician strike can be viewed as proper remedial legislation. Consequently, the sham exception would not prevent the striking physicians from successfully using the Noerr-Pennington defense.

\section{Resistance to Health Maintenance Organizations.}

A third type of trade restraining activity engaged in by medical societies is organized resistance to alternative health care delivery systems such as Health Maintenance Organizations (HMOs) ${ }^{64}$ Medical societies have opposed the concept of prepaid group health care due to its change in the physician's receipt of payment. ${ }^{65}$ One technique for (1961).

61. Eastern R.R. Presidents Conference v. Noerr Motor Freight, Inc., 365 U.S. 127, 144

62. See text accompanying notes 53-60 supra.

63. As an example of the degree of regulation of insurance in the medical malpractice field see CAL. INS. CODE $\S \S 11890-11916$ (West Supp. 1977) (California Medical Malpractice Joint Underwriting Association Act).

64. The medical societies' strong resistance to the HMO concept led to one of the early medical antitrust cases, American Medical Association v. United States, 317 U.S. 519 (1943), in which the AMA's leaders were found criminally liable for coercing physicians into refusing to work for a prepaid group health plan and denying the use of hospital facilities to the group's doctors. Id. at 527. Subsequent resistance has taken a more subtle approach but it continues nonetheless. See Ohio ex rel. Brown v. Mahoney County Medical Soc'y, No. C76-168Y (N.D. Ohio, Aug. 24, 1976) (antitrust suit filed by Ohio Attorney General against local medical society for blocking formation of HMO in Youngstown, Ohio).

65. The primary difference between an HMO and traditional practicing physicians is the method of payment. Under the traditional method a physician charges his fee in relation to the number of services given to the patient. An HMO, by contrast, receives fixed periodic payments 
opposing an HMO is to actively challenge its license application before a state administrative panel. ${ }^{66}$ This type of organized resistance aimed at denying a competitor access to the market is a per se violation of the Sherman Act. ${ }^{67}$ However, in this case the physicians' efforts are directed at a state agency and are within the general scope of the NoerrPennington defense. This defense, though, is limited by the sham exception as applied to influencing activities before administrative agencies.

The sham exception for administrative agencies was first enunciated in California Motor Transport where the Supreme Court held that certain abuses of the adjudicatory process, such as baseless, repetitive claims, are not immunized from antitrust sanctions by the NoerrPennington doctrine. ${ }^{68}$ This exception was subsequently restated in $O t$ ter Tail Power Co. v. United States. ${ }^{69}$ Otter Tail involved four towns that sought to establish their own municipal distribution system in order to purchase electricity at wholesale from the Otter Tail Power Company, the area's sole supplier. ${ }^{70}$ Otter Tail refused to sell any electricity to the towns and instituted law suits in order to halt or delay the municipal systems. ${ }^{71}$ The Court, in restating the California Motor Transport sham exception, found that Otter Tail's repetitive litigation

from subscribers who are given whatever medical services they require within the time period covered by the payments. Schneider \& Sterns, Health Maintenance Organizations and the Poor: Problems and Prospects, 70 Nw. U.L. REv. 90, 94-95 (1975).

66. For example, under Ohio law any person establishing an HMO is required to obtain a certificate of authority from the state Superintendent of Insurance. OHIO REv. CODE ANN. § 1742.02 (Page Supp. 1976). The application for an HMO certificate could be opposed by physicians and possibly lead to a denial of the authority.

67. Activity of this kind is aimed at restricting entry to a competitor and is closely analogous to the classic boycott. See L. Sullivan, supra note 32, at 230. In antitrust terms the classic boycott involves a situation where a group already in business is able to deny the non-group competitors of some trade relationships that the non-group businessmen need to effectively compete. Id. For example, in Klor's v. Broadway-Hale Stores, 359 U.S. 207 (1959), a large chain store retailer used its influence over wholesalers and manufacturers in order to have them refuse to sell to a small competitor of one of Broadway-Hale's stores. Id. at 209. The Supreme Court essentially applied a per se rule, holding the activity of Broadway-Hale, the wholesalers and manufacturers to be so destructive of competition that the reasonableness of the action was not to be considered. Id. at 212.

Similarly, the organized resistance of the medical society is directed at denying the HMO a government license to operate. Just as Klor's could not compete without having a stock of goods to sell, the HMO cannot legally operate its facility and compete with fee-for-service physicians of the medical society without its license. Consequently, the medical society's response to the HMO is an effort to deny an HMO entry to the market and is a per se violation of the Sherman Act.

68. California Motor Transp. Co. v. Trucking Unlimited, 404 U.S. 508, 513 (1972). See text accompanying notes $24-25$ supra.

69. 410 U.S. 366 (1973).

70. Id. at 371 .

71. Id. at 372 . 
and insubstantial claims abused the judicial process and were within this limitation of the Noerr-Pennington doctrine. ${ }^{72}$

Subsequent to California Motor Transport the lower court interpretations of the sham exception have focused either on the repetitiveness of the litigation, ${ }^{73}$ the baselessness of the claim asserted, ${ }^{74}$ or the intent to abuse the adjudicatory process. ${ }^{75}$ While all of these "tests" are part of the sham exception, no one standard has emerged as predominant in determining when an abuse has occurred. Instead, the courts are seeking to find some act reprehensible in terms of the adjudicatory system. Once this act is found, the Noerr-Pennington immunity is stripped from the abusing party and the court returns to an examination of the asserted antitrust violation. ${ }^{76}$

In the case of the medical society's organized resistance to the HMO's license the sham exception is applicable if it can be established that the opposing physicians' claims were baseless. Unlike many other regulatory agencies, which are concerned with the economic impact of a new service on existing providers of that service, ${ }^{77}$ the state agency's

72. Id. at 380 . Specifically, the Court stated that "the principle of Noerr may also apply to the use of administrative or judicial processes where the purpose to suppress competition is evidenced by repetitive law suits carrying the hallmark of insubstantial claims and thus within the 'mere sham' exception." Id. This language is confusing at best, but probably means that when the adjudicatory process is abused by baseless lawsuits, it constitutes a sham. See Note, supra note 25 , at 301 . Fortunately, the lower courts that have addressed the case have correctly interpreted Otter Tail to stand for a reiteration of the sham exception expressed in California Motor. See Franchise Realty Interstate Corp. v. San Francisco Local Joint Executive Bd. of Culinary Workers, 542 F.2d 1076, 1084 (9th Cir. 1976), cert. denied, 430 U.S. 940 (1977); Lektro-Vend Corp. v. Vendo Co., 403 F. Supp. 527, 534 (N.D. Ill. 1975), rev'd on other grounds, 433 U.S. 623 (1977); Bethlehem Plaza v. Campbell, 403 F.Supp. 966, 970 (E.D. Pa. 1975).

73. See Bethlehem Plaza v. Campbell, 403 F. Supp. 966, 970-71 (E.D. Pa. 1975) (one lawsuit not within sham exception). But see Associated Radio Serv. Co. v. Page Airways, Inc., 414 F. Supp. 1088, 1096 (N.D. Tex. 1976) (if intent to abuse exists, one lawsuit sufficient).

74. See Rush-Hampton Indus., Inc. v. Home Ventilating Inst., 419 F. Supp. 19, $22-25$ (M.D. Fla. 1976); B.A.M. Liquors, Inc. v. Satenstein, [1976-2] Trade Cas. (CCH) I 60, 997 at 69, 411-13 (S.D.N.Y.).

75. Associated Radio Serv. Co. v. Page Airways, Inc., 414 F. Supp. 1088, 1094-96 (N.D. Tex. 1976). This case analyzes California Motor in terms of the distinction between a "concerted effort to influence public officials regardless of intent and purpose and the concerted effort to abuse the judicial or administrative process." $J d$. at 1096 . This type of approach necessarily involves a two-step analysis. The court first examines the facts for an act, such as the filing of a baseless claim, and second, looks to find a purpose or intent to abuse the adjudicatory process.

76. Such an approach to a sham activity is consistent with its "activities" orientation. That is, instead of analyzing the type of governmental decision or the relationship between the government officials and the parties involved, the courts will look for acts which in themselves are abuses of the adjudicatory process.

77. For example, in ICC motor carrier authority applications, one factor the Commission specifically considers is whether traffic adequately handled by existing carriers will be diverted to the applicant and thus weaken the financial position of the existing carriers. See, e.g., Grover v. United States, [1976] Fed. Carr. Cas. (CCH) ๆ 82,642 at 57,239 (D. Utah); Terminal Transport Co. 
task in evaluating the proposed HMO focuses on the HMO's ability to deliver quality health care services. The legitimate issues before the state agency are whether the proposed HMO has adequate financing arrangements, whether the proposed facility is able to provide a full range of medical services for its subscribers, and whether adequate arrangements have been made with existing health care providers for additional treatment if the HMO is unable to provide that special service. ${ }^{78}$ Noticeably, none of these issues concern the financial impact on the current practicing physicians in the proposed HMO's service area, even though this issue is likely to be the motivating factor behind the opposition to the HMO's certificate. As a result of the type of issues considered by the state regulatory body, physician opposition has to be based on legitimate health care quality concerns in order for the physicians to avail themselves of the Noerr-Pennington defense. Otherwise, the physician's claims are without merit on the proper issues before the administrative agency and their baseless opposition would fall within the sham exception to the doctrine.

\section{Hospital Staff Privileges.}

Hospital staff privileges allow a physician to admit patients to a hospital and use its facilities for treatment purposes. These privileges are recognized as a professional and financial necessity for the practicing physician. ${ }^{79}$

Those doctors who are admitted as members of the staff are not employees of the hospital, rather they are independent professionals who are permitted to use the hospital's facilities for treatment purposes. ${ }^{80}$ When physicians as independent professionals act in concert

Extension-Birmingham and Florida Area, 103 M.C.C. 699, 715 (1967); Pan-American Bus Lines Operation, 1 M.C.C. 190, 203 (1936).

78. Under the Ohio HMO certification procedure the state Director of Health is to evaluate, inter alia,

1. whether the applicant has demonstrated an ability to provide basic health care services as promptly as needed and in a continuous manner;

2. whether appropriate arrangements have been made for access to specialists which are generally available in the area;

3. whether arrangements have been made for the availability of short-term emergency health care services.

OHo Rev. Code ANN. \$1742.04 (Page Supp. 1976). Further, the Superintendent of Insurance is to evaluate the financial arrangements made with insurers and government agencies, the solvency of the applicant, and the agreements made with participating doctors. Id. $\S 1742.05$.

79. Moore v. Board of Trustees of Carson-Tahoe Hosp., 88 Nev. 207, 213, 495 P.2d 605, 609, cert. denied, 409 U.S. 879 (1972) (Thompson, J., dissenting). Further, hospital staff privileges have been recognized as a property right as well as a personal right. Edwards v. Fresno Community Hosp., 38 Cal. App. 3d 702, 705, 113 Cal. Rptr. 579, 580-81 (1974).

80. See Dickinson v. Mailliard, 175 N.W.2d 588, 594 (Iowa 1970); Hull v. North Valley Hosp., 159 Mont. 375, 387-88, 498 P.2d 136, 142-43 (1972); Southwick, The Hospital's New 
with other doctors to influence the hospital staff committees to deny potentially competing, qualified applicants hospital staff privileges, ${ }^{81}$ these physicians may be violating the antitrust laws. A violation may be found even if the rule of reason rather than a per se approach is deemed appropriate in this context. ${ }^{82}$

In many hospitals the staff privileges review committees can be considered governmental bodies and physician influencing efforts directed at these committees are initially protected by the NoerrPennington defense. Thus the preliminary question is whether the particular hospital's staff privilege review committee is a public entity. In

Responsibility, 17 Clev.-MAR. L. REv. 146, 155 (1968). However, in large hospitals interns, residents and some specialists are employed full-time by the hospital and may be regarded as employees rather than independent contractors. See Hull v. North Valley Hosp., 159 Mont. 375, 387. 88, 498 P.2d 136, 142-43 (1972).

81. See Note, Physician-Hospital Confict: The Hospital Staff Privileges Controversy in New York, 60 CoRNell L. REv. 1075, 1096 (1975). In testimony given before the New York State Senate Committee on Health it was noted that in 1971 as many as thirty percent of the physicians in the New York City area were without staff privileges. Further, the testimony indicated that in Albany many doctors were effectively excluded from the area's most prestigious hospitals. Id. at 1097 n.150 (citing the New York State Senate Committee on Health, Report of ActiviTIES 12-13 (1971)).

82. In antitrust terms the doctors who are members of the staff are using their positions to block competitors from entering the market. Although this action in the commercial world constitutes a per se violation of the Act, see Radiant Burners, Inc. v. Peoples Gas Light \& Coke Co., 364 U.S. 656, 659-60 (1961), in the hospital setting where credentials of the new applicant are being appraised the rule of reason provides the better standard.

Under the rule of reason approach the reasonableness of the anticompetitive activity is examined in light of surrounding circumstances. See Chicago Bd. of Trade v. United States, 246 U.S. 231, 238 (1918). The primary factors to which the courts look are the purpose and effect of the activity. After comparing these two factors any anticompetitive activity that is found unreasonable is held to violate the Act. Id. See also Standard Oil Co. v. United States, 221 U.S. 1, 60 (1911).

Without staff privileges a physician cannot admit patients to the hospital for further treatment but must refer the patient to a doctor who does have the privilege. Since the effect of the denial is to significantly restrict competition, the critical factor becomes the purpose behind the denial. When the applicant is unqualified, it can be inferred that the purpose was to protect the public from the unskilled practitioner, however, when the doctor is qualified but is still denied the privilege, see Greisman v. Newcomb Hosp., 40 N.J. 389, 402-03, 192 A.2d 817, 824-25 (1963), the refusal indicates an anticompetitive purpose behind the decision and hence a violation of the Act.

As further protection for the applicant the antitrust laws require that a self-regulatory body, such as the hospital staff, afford the applicant notice and a hearing on his qualifications. This requirement was established by the Supreme Court in Silver v. New York Stock Exch., 373 U.S. 341 (1963), in which the Stock Exchange in exercising its self-regulatory powers directed its members not to deal with a nonmember broker who used private telephone connections to communicate with member firms. Id. at 343-44. Since the nonmember broker was not informed of the charges against him nor afforded an opportunity to refute these charges in a hearing before the Exchange, the boycott of the nonmember broker was held to constitute a per se violation of the Act. Id. at 361-64. Consequently, even when the qualifications of the physician applicant could be used to justify a denial of staff privileges and thus not give rise to the inference of an anticompetitive purpose, the hospital staffs denial would still be an antitrust violation if it failed to afford the applicant his basic procedural rights. 
the private hospital these committees are appropriately viewed as arms of a private business and not public regulatory groups. ${ }^{83}$ Although the ultimate purpose for the hospital may be to benefit the public at large, this factor does not transform a private entity into a public institution. Consequently, Noerr-Pennington's basic requirement of petitioning the government would not be present and the defense would not be available.

In the public hospital, the question of whether the staff privileges review committee is a public body can be answered by examining numerous cases dealing with the applicability of fourteenth amendment procedural due process rights. In these cases the courts have found such committees to be sufficiently entwined with state and local government to be subject to procedural due process requirements. ${ }^{84}$ If these committees are considered governmental bodies for the purposes of due process, consistency would dictate that the committees be regarded as public bodies for the purposes of the Noerr-Pennington doctrine. Automatic antitrust immunity does not necessarily follow, however. Because of the close ties between the physicians on the committees and those doctors influencing them, ${ }^{85}$ the co-conspirator exception to the

83. Schlein v. Milford Hosp., Inc., 561 F.2d 427 (2d Cir. 1977); Briscoe v. Bock, 540 F.2d 392, 394-96 (8th Cir. 1976); Comment, State Action in the Health Field, 1975 WIS. L. REv. 1188, 1189-90 (and authorities cited therein). See also Jackson v. Norton-Childrens Hosp., Inc., 487 F.2d 502 (6th Cir. 1973). However, the activities of private hospital staff privileges committees may be considered as state action for fourteenth amendment purposes. Duffield v. Charleston Area Medical Center, Inc., 503 F.2d 512, 515 (4th Cir. 1974). By analogy it can be argued that they are performing a quasi-public function making the Noerr-Pennington doctrine applicable. See Rush-Hampton Indus. v. Home Ventilating Inst., 419 F. Supp. 19, $22-25$ (M.D. Fla. 1976).

84. Woodbury v. McKinnon, 447 F.2d 839 (5th Cir. 1971); Sosa v. Board of Managers of Val Verde Memorial Hosp., 437 F.2d 173 (5th Cir. 1971); Jackson v. Fulton-Dekalb Hosp. Authority, 423 F. Supp. 1000 (N.D. Ga. 1976), affd, 559 F.2d 1214 (5th Cir. 1977); Comment, supra note 83, at 1190 (authorities cited therein).

The courts have been willing to give these committees considerable latitude when reviewing their decisions. For example, in one opinion Judge Goldberg stated:

It is the Board, not the court, which is charged with the responsibility of providing a competent staff of doctors. The Board has chosen to rely on its Medical Staff, and the court cannot surrogate for the Staff in executing this responsibility .... The evaluation of professional proficiency of doctors is best left to the specialized expertise of their peers subject only to limited judicial surveillance.

Sosa v. Board of Managers of Val Verde Memorial Hosp., 437 F.2d 173, 177 (5th Cir. 1971). This language implies that the courts are recognizing these committees as a type of administrative body, since the standard used by the courts is similar to that used by courts when reviewing federal administrative agency decisions. See, e.g., FPC v. Florida Power \& Light Co., 404 U.S. 453, 463 (1972); Di Vosta Rentals, Inc. v. Lee, 488 F.2d 674, 678 (5th Cir.), cert. denied, 416 U.S. 984 (1973); Frommhagen v. Klein, 456 F.2d 1391, 1393 (9th Cir. 1972); Montana Wildlife Fed'n v. Morton, 406 F. Supp. 489, $491-92$ (D. Mont. 1976).

85. For one example, see Feminist Women's Health Center, Inc. v. Mohammad, $415 \mathrm{~F}$. Supp. 1258, 1264 (N.D. Fla. 1976), modified, No. TCA 75-186 (N.D. Fla. Dec. 3, 1976), appeal docketed, No. 77-1924 (5th Cir. 1977). 
Noerr-Pennington doctrine is applicable.

This exception was first recognized in Harman v. Valley National Bank. ${ }^{86}$ In this case, Harman's complaint stated that several banks had conspired with the Arizona Attorney General to close a competing savings and loan. ${ }^{87}$ The Ninth Circuit in sustaining the sufficiency of the complaint held that even though these banks were petitioning the Attorney General to use his statutory authority, the Noerr-Pennington defense was not applicable where the government official was involved in a conspiracy with the petitioning group. ${ }^{88}$ Little was stated to support the court's position and the decision itself was disapproved by the Ninth Circuit in Sun Valley Disposal Co. v. Silver State Disposal Co. ${ }^{89}$ Subsequently, the Third Circuit in Duke \& Co. v. Foerster ${ }^{90}$ revived this exception. In Duke a manufacturer and seller of malt beverages alleged that three municipal corporations, three private corporations and a county commissioner had conspired to boycott the manufacturer's product. ${ }^{11}$ The court, in sustaining the validity of the allegations, relied on the fact that "both Noerr and Pennington involved suits against private parties,"92 rather than the collaboration of the government entity in promoting the conspiracy. ${ }^{93}$

This distinction, though essentially correct, glosses over the difficulty involved in looking at the relationship between the parties. The Third Circuit appeared to be distinguishing between the government official who is simply supporting the position of one of the petitioners and the government official who is actively involved in the anticompetitive scheme. When the government official is merely convinced that the public policy would best be served by the approach advocated, the traditional justifications for Noerr-Pennington apply. ${ }^{94}$ However, the doctrine should not apply when the government official has a self-serving motive to benefit a certain group without considering the policy

86. 339 F.2d 564 (9th Cir. 1964).

87. Id. at 566 .

88. $T d$.

89. 420 F.2d 341 (9th Cir. 1969). In disapproving Harman the Ninth Circuit relied on the broad language of the Pennington decision concerning joint activities designed to influence public officials. The court's reliance, though, seems misplaced. Pennington was concerned with a private influence group's anticompetitive efforts rather than the personal monopolistic scheme of an involved government official.

90. 521 F.2d 1277 (3d Cir. 1975).

91. Id. at $1278-79$.

92. Id. at 1282 .

93. Id. The court's opinion relied on Harman as authority for this proposition apparently in disregard of the Sun Valley opinion.

94. See United Mine Workers v. Pennington, 381 U.S. 657 (1965); Eastern R.R. Presidents Conference v. Noerr Motor Freight, Inc., 365 U.S. 127 (1961); Bob Layne Contractor, Inc. v. Bartel, 504 F.2d 1293, 1296 (7th Cir. 1974). 
aspects of the decision. ${ }^{95}$

In the context of the hospital staff review committee the relationship between the committee members and influential physicians is very close because physicians in both groups have a vested financial interest in limiting the number of staff privileges given out. Members of both groups are in constant contact through a daily work relationship and physicians in both groups are usually AMA members. Under these conditions the physician-controlled committees are likely to be operating in conjunction with those doctors seeking denial of the application, since such a recommendation is beneficial to both in limiting competition and maintaining work relationships. Although proof of a conspiracy involves a factual determination, when such a conspiracy is shown, the co-conspirator exception removes the protection given by the Noerr-Pennington doctrine to the petitioning doctors.

\section{E. Medical Peer Review Groups.}

In response to the high cost of health care and the growth in medical malpractice claims, both federal and state government have established physician peer review groups. The prime example of this regulatory measure is the Professional Standards Review Organization (PSRO) ${ }^{96}$ Under this program those practitioners who provide health care to patients under federally-funded medical programs ${ }^{97}$ can be reimbursed only when the local PSRO certifies that the services rendered were medically necessary, in accord with professional standards or norms of medical care, and incapable of being rendered at a lower cost through use of alternative types of treatment. ${ }^{98}$ In order to implement

95. See Duke \& Co. v. Foerster, 521 F.2d 1277, 1281-82 (3d Cir. 1975); Harman v. Valley Nat'l Bank, 339 F.2d 564, 566 (9th Cir. 1964). The difficulty in determining when the "line" is crossed between these two types is well illustrated by Metro Cable Co. v. CATV of Rockford, Inc., 516 F.2d 220 (7th Cir. 1975). In this case it was alleged that the mayor and one alderman were involved in a conspiracy to grant a cable television license to one company. The company obtaining the license had given large campaign contributions to both of these officials. The court, however, chose to construe these payments as merely campaign donations and not bribes. Thus, the co-conspirator exception was found not applicable. Id. at 230; see Note, Antitrust NoerrPennington Doctrine-Metro Cable Co. v. CATV of Rockford, Inc., 17 B.C. Indus. \& CoM. L. REv. 511,517-18 (1976).

96. In 1972 Congress passed the PSRO law in order to stem the rise in medical costs. 42 U.S.C. $\$ \$ 1320$ c to $1320 \mathrm{c}-19$ (Supp. V 1975). Subsequently, in 1975 the PSRO legislation was found constitutionally acceptable. Association of Physicians and Surgeons v. Weinberger, $395 \mathrm{~F}$. Supp. 125 (N.D. Ill. 1975). For a description of the statute and its requirements see J. BLUM, P. GERTMAN \& J. RABINOW, PSROS AND THE LAW 19-57 (1977).

97. The programs include Maternal and Child Health Care, 42 U.S.C. $\$ \S 701-716$ (Supp. V 1975); Medicare, 42 U.S.C.A. $\S \S 1395-1395 q q$ (West Supp. 1977) and Medicaid, 42 U.S.C.A. $\S \S$ 1396-1396j (West Supp. 1977).

98. 42 U.S.C. $\& 1320 \mathrm{c}-4$ (Supp. V 1975). The program is intended to expand to cover all 
the PSRO program, the PSRO is charged with determining norms of care, diagnosis and treatment based on typical patterns of practice in the PSRO's region. ${ }^{99}$

In addition to the federal PSRO program some states have either implemented state PSROs ${ }^{100}$ or granted existing physician groups such as hospital staffs and medical societies self-regulatory powers. ${ }^{101}$ Within the framework of those peer review groups there exists the potential for doctors to use them for anticompetitive purposes.

This use of a peer review group for anticompetitive purposes is demonstrated by Feminist Women's Health Center, Inc. v. Mohammad. ${ }^{102}$ In this case the Feminist Women's Health Center (Center), an abortion clinic, began operations in Tallahassee, Florida in June of $1974{ }^{103}$ From that time until July, 1975, local physicians practiced at the Center without significant interference from other physicians in the community. In June, 1975 a local newspaper investigated local abortion services and compared the cost of an abortion at the Center- $\$ 150.00$ - with the $\$ 400.00$ charged by local obstetricians for comparable services. ${ }^{104}$ After the article was published, the local obstetrician working at the clinic quit. ${ }^{105}$ At the same time the local obstetricians, acting through the Obstetrics and Gynecological (OB-GYN) staff of the area's only hospital and led by doctors who competed with the Center for abortions, refused to associate with the Center on the basis of some advertising it had done. ${ }^{106}$ Further, the OB-GYN staff wrote to

services provided by health care practitioners under federally-funded programs. 42 U.S.C. § $1320 \mathrm{c}-4$ (g) (Supp. V 1975). For a discussion of the PSRO's ability to contain health care costs see Havighurst \& Blumstein, Coping with Quality/Cost Trade-Offs in Medical Care: The Role of PSROS, 70 Nw. U.L. REv. 6 (1975).

99. 42 U.S.C. $\$ 1320$ c-5 (Supp. V 1975). The regional area to be covered by a PSRO was contested in Texas. The state medical society sought to have a single statewide region while HEW had divided the state into nine districts. The district court in that case found that HEW's decision was based on undue influence from congressional sources and set aside HEW's plan. Texas Medical Ass'n v. Mathews, 408 F. Supp. 303 (W.D. Tex. 1976).

100. A few states have established peer review groups to promulgate norms and/or investigate the quality of care being rendered by licensed practitioners. CoLO. REv. STAT. $\S \S 12-43.5-$ 101 to 12-43.5-103 (Supp. 1976); MD. AnN. Code art. 43, § 134A (Supp. 1977); MinN. STAT. ANN. $\S \S 145.61-.67$ (West Supp. 1977); Wro. STAT. $\$ \$ 35-528$ to 35-530 (Cum. Supp. 1975).

101. FLA. STAT. ANN. $\$ 395.065$ (West Supp. 1977) (currently under legislative review, FLA. STAT. ANN. \& 11.61 (West Supp. 1977)).

102. 415 F. Supp. 1258 (N.D. Fla. 1976), modified, No. TCA 75-186 (N.D. Fla. Dec. 3, 1976), appeal docketed, No. 77-1924 (5th Cir. 1977).

103. Id. at 1265 .

104. Id. at 1264-65.

105. Id. at 1265. After the release of the newspaper story the physician who quit working at the Center stated that he would provide informal back-up care but "would not enter into a formal agreement for fear of incurring the animosity of his fellow obstetricians whose goodwill is essential to his practice." Id.

106. Id. One of the leaders in the OB-GYN staff, Dr. Mohammad, admitted to another 
the local medical society stating that the Center had advertised and that no physician should associate with it. ${ }^{107}$

Upon the refusal of local doctors to participate with the Center, it obtained the services of two residents from a Jacksonville, Florida hospital. ${ }^{108}$ The Tallahassee doctors became aware of these new doctors and the OB-GYN staff decided to send a letter to the residents and the head of the Jacksonville residency program stating their disapproval of the residents' work at the Center. ${ }^{109}$ This letter stated that the Center had inadequate backup arrangements with local doctors in case of complications and that such practice was disapproved of by physicians in the local community as falling below the area's medical standards. ${ }^{110}$ On the basis of this letter and the Center's controversial position, the two residents also quit working for the Center. ${ }^{111}$ Faced with a boycott of local doctors, the Center filed an antitrust action against them. In order to continue its abortion services, the Center moved for a preliminary injunction against the OB-GYN staff's refusal to work. ${ }^{112}$

In this case the competing doctors' activity in eliminating the Center's supply of physicians can be characterized as a classic boycott. ${ }^{113}$ The doctors used their leadership positions on the hospital staff peer review group to impede the competing Center's "supply" of physicians. Under traditional antitrust analysis, this constitutes a violation of the Sherman Act. ${ }^{114}$

doctor that his main opposition to the center's practices at the beginning was that the Center was financially embarrassing his own abortion practice. Id. at 1266 .

107. Id. at 1265 . In response to this letter the medical society conducted an investigation of the Center's activities. Brief for Appellant at 19-22.

108. 415 F. Supp. at 1266 .

109. Id.

110. Id

111. Id. at $1266-67$.

112. Id. at 1262 .

113. See L. Sullivan, supra note 32, at 230.

114. This case is not unlike Klor's v. Broadway-Hale Stores, 359 U.S. 207 (1959), in which the Supreme Court essentially applied a per se rule and held unlawful the actions of a large chain store retailer. The store had used its influence over wholesalers in order to have them refuse to sell to a small competitor of the chain store. See note 67 supra. In Feminist Women's Health Center, as in Klor's, a powerful provider had used its influence to cut off the necessary supplies of a competitor. Using a Klor's analysis, the doctor's actions would constitute a per se violation of the Sherman Act.

However, the competing doctors were operating within a professional group that had selfregulatory powers, see note 118 infra, as distinguished from Klor's where Broadway-Hales Stores and Klor's were merely retail competitors. Since the competing doctors had self-regulatory power over the actions of their colleagues, it may have been reasonable to influence the doctors to leave the Center if these doctors were performing substandard work. This recognition of the professional setting suggests that the rule of reason's purpose and effect test is the better approach to use in evaluating the anticompetitive activity. In this case the effect is clearly anticompetitive. The purpose, however, depends upon the reason behind the competing doctors' activity. Since the peer 
As one defense to the antitrust claim, the physicians asserted that communications with the medical society and the Jacksonville hospital staff, as well as communication within the local OB-GYN staff were covered by the Noerr-Pennington doctrine. ${ }^{115}$ The district court initially rejected this defense, stating that the hospital staff medical review committees and the local medical society were private bodies, not state sanctioned regulatory groups, ${ }^{116}$ and thus Noerr-Pennington did not apply.

Subsequently, the defendant physicians presented the district court with additional evidence showing first, that hospital staffs and medical societies were required by statute to furnish the State Board of Medical Examiners with information of any disciplinary actions taken against member doctors, ${ }^{117}$ and second, that hospital staffs were authorized by the state to engage in disciplining their members. ${ }^{118} \mathrm{On}$ the basis of this statutory scheme the district court reversed itself and characterized the medical society and the two hospital staffs as quasi-public bodies. ${ }^{119}$ This characterization enabled the court to apply the Noerr-Pennington doctrine to the influencing activities of the obstetricians, both as individuals and as a staff. Since these activities provided the basis for the Center's antitrust claim, the application of the Noerr-Pennington defense immunized the physicians from antitrust liability. ${ }^{120}$

In determining whether the medical society and the hospital staffs were quasi-public bodies, the court used a straightforward state action analysis. It looked to the statutory duty to report disciplinary actions ${ }^{\mathbf{1 2 1}}$

review group did not concern itself with any disciplinary actions against the doctors who worked at the Center, but preferred merely to have these doctors quit the Center, the suggested purpose for the action was the removal of a competitor from the market. Without a legitimate purpose to offset the anticompetitive effect, the doctors' use of their power and influence over other physicians was unreasonable and a violation of the Act.

115. 415 F. Supp. at $1268-69$.

116. Id.

117. See Fla. Stat. ANn. § 458.1201(1)(p) (West Supp. 1977). This statute provides that any medical association, PSRO or similar body, or hospital staff which takes disciplinary action against a member physician is to report such action to the Board of Medical Examiners within thirty days of its occurrence. Id.

118. Id. $\$ 395.065$ (West Supp. 1977) (currently under legislative review. Fla. Stat. ANN. $\S 11.61$ (West Supp. 1977)). This statute provides, in part, that

[t] he medical staff of any hospital licensed pursuant to this chapter is authorized to suspend, deny, revoke, or curtail the staff privileges of any staff member for good cause

pend

Id.

119. Feminist Women's Health Center, Inc. v. Mohammad, No. TCA 75-186 (N.D. Fla. Dec. 3, 1976), appeal docketed, No. 77-1924,(5th Cir. 1977).

120. Id. The court entered summary judgment against the Center.

121. Id. 
and the state policy of permitting physician self-regulation ${ }^{122}$ and concluded that the activities of the medical societies and hospital staffs were governmental in nature.

The district court's adoption of a state action analysis to cover all activities of these organizations, however, is questionable in light of the Supreme Court's decision in the analogous field of antitrust state action immunity. In Cantor v. Detroit Edison Co. ${ }^{123}$ the Court expressed its intention to narrowly construe the antitrust immunity given private organizations for following the dictates of the state. ${ }^{124}$ According to one analysis of Cantor, in order to qualify as state action the state not only has to expressly mandate the action, but it must be shown that first, the private group is acting pursuant to a statutory mandate which compels the action, second, the state statute is repugnant to the federal antitrust laws, third, the state's interest in creating the statutory scheme outweighs the antitrust policies, and finally, in order to achieve the goals of the state scheme, it is necessary to immunize the actions of the private group. ${ }^{125}$

Applying Cantor's restrictive approach to the hospital staffs and medical society in Feminist Women's Health Center suggests that only the reporting of disciplinary actions of their member physicians would satisfy the above criteria. ${ }^{126}$ Because this reporting of disciplinary action is only one activity out of many performed by the hospital staffs and medical societies, Cantor would not clothe these groups with state action antitrust immunity for all purposes. This direct comparison with Cantor, though, must be tempered by the physicians' status as professionals and the traditional state policy permitting self-regulation

122. Id.

123. 428 U.S. 579 (1976).

124. In Cantor the Detroit Edison Company, an electric utility, had engaged in a light bulb exchange program for years with the tacit approval of the state regulatory agency. A competitor in the light bulb market claimed that the exchange program was in violation of the Sherman Act. In deciding the validity of Detroit Edison's state action defense, the Court found that the program was not initiated by the state and that there was no basic state policy behind its sanctioning of the exchange program. For a general discussion of the Cantor decision see Comment, The State Action Exemption in Antitrust: From Parker v. Brown to Cantor v. Detroit Edison Co., 1977 DukE L.J. 871.

125. Dorman, State Action Immunity: A Problem Under Cantor v. Detroit Edison, 27 CASE W. RES. L. REv. 503, 520-21 (1977).

126. Under the Cantor analysis the reporting function is clearly mandated by state statute (Fla. Stat. ANN. \$ 458.1201(1)(p) (West Supp. 1977)), could at times affect a competing doctor and be contrary to the federal antitrust laws, involves the state's significant interest in health care, and is part of the state regulatory program.

The hospital staff's statutorily granted disciplinary power (FLA. STAT. ANN. \$ 395.065 (West Supp. 1977)) would not satisfy a strict Cantor analysis as the statute is not phrased in mandatory terms compelling the hospital staffs to engage in disciplinary proceedings. 
of doctors' activities. Clearly, the courts have given greater leeway in terms of antitrust enforcement to professional activities than those of commercial enterprises. ${ }^{127}$ However, the fact that doctors enjoy a professional status should only serve to extend Cantor's antitrust immunity to those activities of the hospital staffs and medical societies that directly contribute to the improvement of the professional service to the public. ${ }^{128}$

By comparison the characterization of the hospital staffs and medical societies as quasi-public for purposes of the Noerr-Pennington doctrine should only extend to those functions that directly relate to the public interest as expressed through the state's health care regulatory policy. In Feminist Women's Health Center, only the formal disciplinary proceedings invoked against physicians should rise to the level of quasi-governmental status with immunity extended only to that aspect of the staff's and the society's activity. ${ }^{129}$

Tested by this standard the activities of the Tallahassee and Jacksonville hospital staffs and the Capital Medical Society do not constitute quasi-governmental functions. Clearly the Tallahassee OB-GYN staff was not concerned with the incompetence of its own members, but rather was concentrating on a competing non-member organization-the Center-over which the staff had no power to discipline for

127. For example, in Goldfarb v. Virginia State Bar, 421 U.S. 773 (1975) the Court stated that

it would be unrealistic to view the practice of professions as interchangeable with other business activities, and automatically to apply to the professions antitrust concepts which originate in other areas. The public service aspect ... . of the professions may require that a particular practice, which could properly be viewed as a violation of the Sherman Act in another context, be treated differently.

Id. at 787 n.17.

128. In Boddicker v. Arizona State Dental Ass'n, 549 F.2d 626 (9th Cir.), cert. denied, 434 U.S. 825 (1977) the Ninth Circuit harmonized Cantor's strict state action stand with Goldfarb's expressed leniency to the professions by stating that

to survive a Sherman Act challenge a particular practice, rule, or regulation of a profession, whether rooted in tradition or the pronouncements of its organizations, must serve the purpose for which the profession exists, viz. to serve the public. That is, it must contribute directly to improving service to the public. Those which only suppress competition between practitioners will fail to survive the challenge.

549 F.2d at 632. Similarly, the Supreme Court in National Soc'y of Professional Eng'rs v. United States, 98 S. Ct. 1355 (1978), also restricted the reach of Goldfarb by noting that the cautionary footnote in Goldfarb . . . cannot be read as fashioning a broad exemption under the Rule of Reason for learned professions. We adhere to the view expressed in Goldfarb that, by their nature, professional services may differ significantly from other business services, and, accordingly, the nature of the competition in such services may vary. Ethical norms may serve to regulate and promote this competition, and thus fall within Rule of Reason ....

[However], the Rule of Reason does not support a defense based on the assumption that competition itself is unreasonable.

Id. at 1367-68 (footnote omitted).

129. See Fla. Stat. ANN. $\$ \S 395.065,458.1201(1)(p)$ (West Supp. 1977). 
improper medical care. ${ }^{130}$ So too, the medical society was investigating the Center's practices and not that of one of its member physicians. ${ }^{131}$ Finally, the communication to the Jacksonville hospital staff was not directed at the incompetence or negligence of one of its residents, but rather at the Center's lack of back-up arrangements. ${ }^{132}$

Since none of these organizations were functioning in a recognized quasi-governmental capacity, their status was that of a private organization and whatever communication or influencing efforts passed between them was in a private capacity. Consequently, the NoerrPennington defense should not have been applicable.

Beyond the immediate issues involved in Feminist Women's Health Center is the question concerning the use of the Noerr-Pennington doctrine when a peer review group is functioning within its quasi-governmental capacity, but its power to discipline is used against a member physician for anticompetitive purposes. The situation can be portrayed by changing slightly the facts in Feminist Women's Health Center. Instead of the hospital staff directing its actions against the Center, the setting is changed so that sanctions are sought to be imposed directly on the doctors who performed the Center's abortions. Competing staff doctors would then be simultaneously functioning in two roles: first as a group seeking to influence a governmental unit to reach an anticompetitive decision favorable to them and second as part of the governmental body being influenced. Because the influencing activity is combined with doctors' status in the second role as members of a governmental body, the premise behind the co-conspirator exception can be applied.

As noted above, the underlying rationale of the co-conspiracy exception is that the government officials who are being petitioned are not functioning in their proper capacity of weighing the various policy considerations, rather they are furthering their own economic self-interest. ${ }^{133}$ Since in this example the competing doctors used their position for the purpose of eliminating a competitor rather than judging the medical ability of the "disciplined" physician, the same reasoning exists for applying the exception. ${ }^{134}$ The only difference between this ex-

130. See text accompanying notes 106-07 supra.

131. See note 107 supra.

132. See text accompanying notes 109-10 supra.

133. See text accompanying notes $94-95$ supra.

134. The use of the co-conspirator exception's underlying rationale is supported by the Supreme Court's decision in Gibson v. Berryhill, 411 U.S. 564 (1973). In that case a state association of private practice optometrists sought to have the State Board of Optometry revoke the licenses of all competing optometrists who were employed by business corporations. Since the Board was composed exclusively of private practice optometrists, the Court disqualified the Board 
ample and the context in which the exception developed is that the influencing group is itself a part of the governing body rather than an outside group of competitors who are in league with the members of the governing body. This factual difference is necessarily due to the peer review group's organization as a state sanctioned group of competitors who are given the power to police their own conduct. However, this distinction does not change the policy behind denying the influencing group the protection of the Noerr-Pennington doctrine as the physicians in their role as government officials are not fulfilling their task in regulating the quality of the area's health care, but are using their position for economic gain. ${ }^{135}$

\section{CONCLUSION}

Despite the broad wording and liberal application of the NoerrPennington doctrine in a commercial antitrust action, the use of the doctrine in a medical antitrust case should be limited. As the five case studies suggest, application of the doctrine should be controlled by two primary considerations: the definition of the group being influenced (as private or governmental), and the various judicially recognized exceptions. Any physician-dominated regulatory group that is subject to doctor-instigated lobbying efforts should be firmly tied to the state's regulatory scheme in order to be characterized as a governmental body, and Noerr-Pennington immunity should extend only to those activities of the group that are directly concerned with regulation, such as discipline for malpractice. By the same token, the various judicially created exceptions to Noerr-Pennington immunity should be liberally applied so as to restrict immunity from antitrust regulation. Although Noerr-Pennington is a valid device for insuring that the antitrust laws do not restrict the private sector's access to government, it is used perversely in situations where the "governmental body" that is asked to sanction anticompetitive activity is really nothing more than the private sector itself, slightly reconstituted and relabelled.

from hearing the charges due to the possibility of the Board using its position for economic gain. Id. at 578-79. Although this case involved a question of procedural due process, it reinforces the premise that members of a governmental body are not properly fulfilling their assigned task when the purpose or potential purpose behind their action is personal economic gain.

135. With the co-conspirator exception's emphasis on the purpose behind the physicians' influencing activity the burden of proof becomes a key factor in the exception's usefulness. Although the burden is usually placed on the complainant to show an exception to an affirmative defense, such as the Noerr-Pennington doctrine, in this case the potential for an anticompetitive purpose is so great that the defending physicians should be required to show a non-economic purpose behind their action in order to avail themselves of the defense. 
